\title{
The Effect of Execution the Privatization Program on the Final Account (The Actual Revenues and Expenditures) in Jordan
}

\author{
Nawaf Abdallah Aljundi ${ }^{1} \&$ Ibrahim Ali Alqadi ${ }^{1}$ \\ ${ }^{1}$ Middle East University, Accounting and Finance Department, Jordan \\ Correspondence: Nawaf Abdallah Aljundi, Middle East University, Accounting and Finance Department, Jordan. \\ E-mail: morganiteinstitute@yahoo.com
}

Received: February 10, 2018

doi:10.5539/ijbm.v13n12p93

\begin{abstract}
The purpose of this study was to evaluate the impact of the privatization program in Jordan on the final account of the state (actual revenues and expenditures), the study used the ratio of the size of the local revenues, the size of the grants, the size of the recovered loans, the volume of current expenditures, and the volume of investment expenditures to the size of the state budget for each year of study, the study is based on the financial data of the volume of revenues and actual expenditures of the State issued by the Ministry of Finance and the General Budget Department for the period of study. The methodology of the study is to calculate and compare the average of each indicator of study for ten years before the year of implementation of the privatization program and ten years after, t-test was used for independent samples. The study found that there is no statistically significant effect of the implementation of the privatization program on the size of the local revenues or on the size of the grants or on the volume of investment expenditures. However, the implementation of the program has a statistically significant impact on the size of recovered loan installments, and the size of the current expenditure.

The results of the study indicate that the implementation of the privatization program in Jordan did not contribute to reducing the financial burden on the general budget. The study recommended that the implementation of the strategic programs and projects should be planned well and that the best practices and procedures are universally recognized in the implementation of these programs. And take into account all the factors that help these programs achieve their goals.
\end{abstract}

Keywords: privatization program, final account, actual revenues, expenditures

\section{Introduction}

Privatization in its current sense is a relatively recent phenomenon. Its origins date back to the seventh decade of the last century, when America began privatizing some sectors, starting with the transport, energy, telecommunications and steel industries. Privatization is defined as "An act of economic sovereignty or a manifestation of its functions, which the legislature is specialized in its execution, a process intended to transfer the ownership of state-owned public enterprises to the private sector in order to achieve social, economic and political imperatives" (Al-Za'arir, 2003). In economic terms, privatization is defined as "removing barriers to the private sector's ability to provide services or to benefit from the infrastructure necessary to deliver these services" (Shehadeh, 2002). In Jordan, however, the Privatization was defined as "the adoption of an economic approach to strengthen the role of the private sector in economic activity to include public sector projects whose nature requires management on Commercial basis"(Privatization Law, 2000).

Privatization is one of the financial reform programs that countries resort to in order to remedy the imbalance in their financial situation by controlling their expenditures, improving the sources of their financial resources and improving the use of these resources. Privatization is often one of the requirements of external financing institutions such as the International Monetary Fund and the World Bank which seek to improve the capacity of debtor countries to service their external debt through improving their sources of income and adjust their expenses and thus reduce the proportion of deficits in their budgets, and directly affects the final account of the state, which reflects the result of the actual implementation of the general budget compared to the general budget estimates and includes details of the actual revenues and expenditures for the previous year, and in Jordan it includes data on local revenues, grants and premiums on the revenue side, current expenditures and investment 
expenses on the expenditure side, thus giving a more detailed picture of the financial changes in the financial state budget compared to what the public budget deficit study gives as a total number and is complementary to the income side of the general budget.

\subsection{The Purpose of the Study}

This study aims to identify the impact of the implementation of the Privatization Program on the final account (actual revenues and expenditures) of the State in Jordan from the following aspects:

- The size of the actual public revenues and their components and their proportion to the total public expenditure

- The size of the actual public expenditure and its components and the proportion of each of them to the total public expenditure.

\subsection{The Problem of the Study and Its Questions}

The reduction of the financial burden on the public budget is considered one of the main objectives of the privatization programs in many countries. Privatization is supposed to eliminate or reduce the burden of state support for losing public companies and institutions or increase their revenues from these privatized companies and institutions (Sunderland, 2011),the Jordanian government considered that reducing the burden on the public budget was one of the objectives of the Privatization Program in Jordan (Privatization Law, 2000). Studies commissioned by the Executive Privatization Authority, the government arm of the Privatization Program, indicated that the Jordan Privatization Program is the most successful in the Middle East, in terms of methodology, the speed of completion of transactions, and revenues achieved (Executive Privatization Commission, 2006).Therefore, the problem of the study is to answer the following main question: Does the implementation of the privatization program affect the final account (revenues and actual expenditures) of the state in Jordan? The following sub-questions arise from this question:

- Has the implementation of the Privatization Program in Jordan affected the actual domestic revenues of the State, expressed by the percentage of domestic revenues to the size of the State's general budget in Jordan?

- Has the implementation of the Privatization Program in Jordan affected the actual amount of grants received by the State, expressed by the size of grants granted by the State to the size of the State's general budget in Jordan?

- Has the implementation of the Privatization Program in Jordan affected the amount of actual recoveries received by the State, expressed by the size of the installments of the recovered loans to the size of the State's general budget in Jordan?

- Has the implementation of the privatization program in Jordan affected the current actual expenditure of the state, expressed by the percentage of current expenditures to the size of the state budget in Jordan?

- Has the implementation of privatization program in Jordan affected the actual investment expenditure of the country, expressed by the size of the investment expenditures to the size of the general budget of the state in Jordan?

\subsection{Importance of the Study}

This study is complementary to the studies that dealt with the Privatization Program in Jordan, and in particular the studies that dealt with the extent of achieving the goals set by the government. The importance of this study stems from the following:

- That there is a great debate in the political and economic circles, and members of the community on the extent of achieving the privatization program of the objectives for which it was implemented, and this study seeks to highlight one of the most important aspects which is the goal of reducing the burden on the state budget.

- The government is aiming to resume the privatization program again, as the projects nominated for privatization during the next decade are worth more than (10) billion dinars, which necessitates benefiting from the past experience and avoid its flaws if any (Al-Jundi, 2015).

- This study is based on actual government revenues and expenditures and not on general budget estimates.

1.4 Hypotheses of the Study

The study includes the following hypotheses: 
- The first main hypothesis (HO1): There are no statistically significant differences between the ratios of the size of the local revenues of the state in Jordan to the size of the state budget before and after the implementation of the privatization program at a significant level $(\alpha \leq 0.05)$.

- The second main hypothesis (HO2): There are no statistically significant differences between the size of grants granted by the state in Jordan to the size of the general budget of the state before and after the implementation of privatization program at a significant level $(\alpha \leq 0.05)$.

- The third main hypothesis (HO3): There are no statistically significant differences between the ratios of the volume of loans recovered by the State in Jordan to the size of the general budget of the State before and after the implementation of the privatization program at a significant level $(\alpha \leq 0.05)$.

- The fourth main hypothesis (HO4): There are no statistically significant differences between the ratios of the volume of current expenditures of the state in Jordan to the size of the general budget of the state before and after implementation of the privatization program at a significant level $(\alpha \leq 0.05)$.

- The fifth main hypothesis (HO5): There are no statistically significant differences between the size of the investment expenditure of the state in Jordan to the size of the state budget before and after implementation of the privatization program at a significant level $(\alpha \leq 0.05)$.

\subsection{Study Model and Its Variables}

\subsubsection{Study Model}

The model of the following study shows the relationship between the independent variable of the study in the implementation of the privatization program and the following dependent variables:

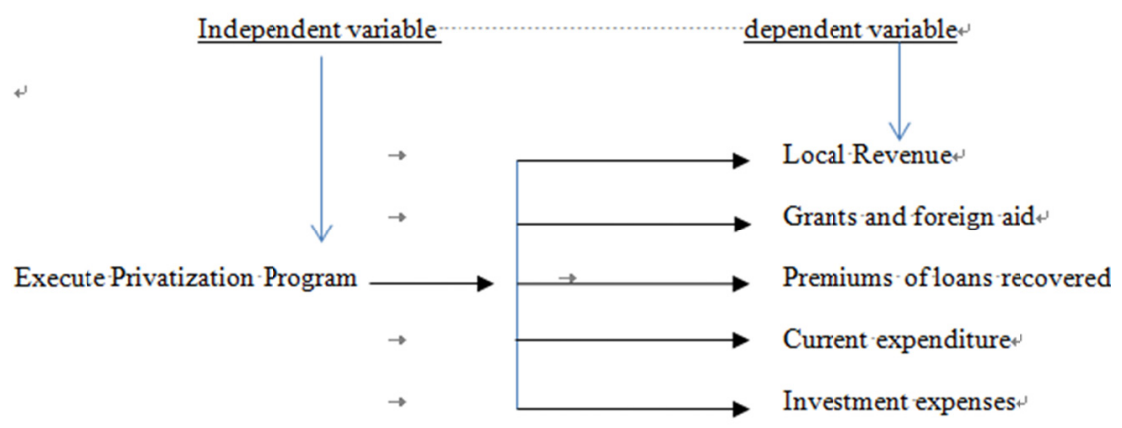

\subsubsection{Study Variables and Its Measurement Dimensions}

1) The local revenues are measured by the size of the local revenues to the size of the general budget.

2) Grants and foreign aid are measured by the size of grants and foreign aid to the size of the general budget.

3) The premiums of recovered loans are measured by the size of grants and foreign aid to the size of the general budget.

4) Current expenditures are measured by the volume of current expenditures to the size of the general budget.

5) Investment expenditure is measured by the size of investment expenditure to the size of the general budget.

\subsection{Limitations of the Study}

1. The difficulty of separating the effect of privatization from the effect of other factors that can affect the state budget, its expenditure and its revenues. Therefore, this study and similar studies are usually conducted to impose the reliability of other factors than privatization.

2. The lack of adequate financial data at the Ministry of Finance on the amount of support provided by the government to companies and institutions privatized before privatization and subsequent change, as indicated by studies conducted by the Executive Privatization Commission, which forced the researcher to compare the proportions of the components of the general budget before And after privatization to achieve the goal of his study. 


\subsection{Procedural Definitions of Terms}

- Final Account: Is a document that includes financial and explanatory statements of actual expenses and revenues collected for the ended financial year in comparison to the general budget appropriations (Shobaki \& Abu Shammala, 2012).

- The General Budget: The government plan for the next fiscal year to achieve the national objectives within the framework of the medium-term financial framework (Regulation of the General Budget No. 58 of 2008, Article 2).

- Local Revenue. Is the revenues obtained by the government using its sovereign powers, including tax and non-tax revenues and includes chapters (1-9) in the General Budget Law (Ismail \& Adas, 2010).

- Repayment of loan repayments: it represents the installments and interest of the restructured loans, and considered as non-tax revenues and is included in Chapter 10 (Ismail \& Adas, 2010).

- Financial Grants: It includes grants received by the government from various sources include Chapter XI of revenues (Ismail \& Adas, 2010).

- Current expenditure: These include compensation of employees, use of goods and services, benefits and trusts, grants, social benefits and other expenses (Ismail \& Adas, 2010).

- Capital expenditures: It includes non-financial assets and includes fixed assets and supplies (Ismail \& Adas, 2010).

- The size of the actual public budget: It is the total public expenditure or actual public revenues of the state, whichever is greater during any year of study (researcher).

- General expenses: the amounts allocated to the government departments to finance all items of current and capital expenditure according to the General Budget Law (Law of Organizing the General Budget No. 58 of 2008, Article 2).

- General revenues: All taxes, fees, revenues, profits, surpluses, grants and any money received by the General Treasury (Law No. 58 of 2008, Article 2).

- Privatization is a systematic and sustained process supported by strong political will aimed at creating a supportive environment for sustainable economic growth. This is the redistribution of roles between the public and private sectors (Privatization Authority, National Privatization Strategy, 1999).

- $\quad$ Law: Privatization Law No. 25 of 2000.

- Starting the implementation of privatization program. Is the year in which the privatization law was issued in 2000 .

- General Budget Deficit: It is the increase in total expenditure (current and investment) on the total revenue in all its forms, local and external, and therefore it is affected by the change in expenditure or income or both.

\section{Theoretical Framework of the Study and Previous Studies}

\subsection{Theoretical Framework}

Jordanian governments began the privatization process in 1988, although there was no legal framework for the privatization process, which specifies the projects that are nominated for privatization and the methods used to implement the privatization process in addition to the goals and objectives of the privatization process, and how to exploit its returns, therefore, the government started to create the appropriate environment for the implementation of the program. It started with the restructuring phase, during which some government sectors such as telecommunications and electricity were converted into state-owned public shareholding companies, and some laws were amended to prevent the private sector from owning projects, and some other economic laws such as corporate and tax laws and others, and finally the issuance of the National Strategy for Privatization and Privatization Law in 2000 and its system in 2008.

\subsubsection{Justifications for Privatization}

The governments that carry out privatization programs provide justification for carrying out this process because the implementation of the process is often faced by opposition from some parties such as trade unions and the owners of economic trends rejecting the approach of the exit of governments from the economic activity of the state. The study of Lotfi (2010) indicated that rationalization of the state's financial actions, the deepening of the utilization of financial resources, the removal of the burden of financing government projects from the state, and the increase in government revenues are among the main reasons given by governments to implement 
privatization programs (Shehadeh, 2002), the Jordanian government has provided the following justification for implementing the Privatization Program Implementation of Privatization Program (Hassouna et al., 1998):

1) Increase economic growth and encourage investment opportunities.

2) To eradicate the phenomenon of competition between the public and private sectors.

3) Raising the efficiency of the Jordanian economy and improving its performance.

4) Correct structural imbalances in the balance of payments.

5) To improve the financial position of the Government.

Some studies have also pointed out that the privatization objectives may sometimes have some conflict, such as between increasing the volume of foreign investments and the aim of expanding the ownership base in privatized companies. The foreign investor may require a high share of privatized companies (Hazaima, 2004). Some studies have indicated that privatization is often aimed at reducing the size of the deficit in the general budget, increasing revenues, raising the performance and efficiency of government companies to be privatized, and introducing new technology (Omran, 2001).

\subsubsection{The Objectives of Privatization in Jordan}

The Privatization Law sets out the objectives of raising the efficiency of economic projects and contributing to encouraging local, Arab and international investments by providing an attractive investment climate, stimulating private savings and directing them towards long-term investment. (Christen and Kogur, 2009). The main objective of the privatization process in Jordan is to reduce the debt burden of the treasury while improving financial and operational efficiency at the institutional level.

\subsubsection{Privatization Relationship with Government Revenues}

The effect of privatization on government revenues differs from state to state and depends mainly on the purpose of privatizing government sectors or companies and on how countries use privatization revenues that are often determined by law. Privatization proceeds can be considered public revenues for the year they have been achieved, and thus contribute to the reduction of the budget deficit in that year as indicated by the study of (Garvalho, 2011) and the study (Davis et.al, 2000), the legislation also states that governments cannot consider these returns as revenues and use them to finance current expenditures, but also to other uses such as external debt repayment and servicing, the purchase of capital assets or the implementation of investment projects (Gangadharan \& Gurusamy, 2012).

In the long run, privatization is assumed to have a positive impact on government revenues if privatization achieves the desired objectives, namely, raising the operational and financial efficiency of privatized companies and providing an attractive investment environment. Studies conducted locally and externally have shown that privatized government companies are improving their operational and financial efficiency (Omran, 2001) and (Oqdeh and Abu Nassar, 2011), thus increasing their profits and increasing the tax revenues of the government of these companies, as a result, privatization, as the main component of economic reform programs imposed by countries and international creditor bodies on debtor countries, is supposed to increase the latter's access to grants and foreign aid.

As for the loan repayments, it is assumed that privatization will improve the ability of government companies to repay the loans that were provided by the government prior to privatization. The reform programs include improving the collection methods and the government's collection of public funds whether loans or taxes due or otherwise known in Government accounting. The expenses that are recovered in the year other than the year in which they were paid are credited to the year in which they were recovered (Ismail \& Adas, 2010).

\subsubsection{Privatization Relationship with Government Expenditure}

a. Current expenditure. Reducing government expenditure is one of the most important government incentives for implementing privatization programs. Privatization is expected to reduce government subsidies to its own companies (Sheshinski \& Lopez-calva, 2003, P439). Therefore, these companies and sectors are often characterized by a decrease in their financial and operational efficiency and a decrease in their returns on the assets invested in them (Kannan, 2001). This is undoubtedly reflected in an increase in government expenditure if these companies and sectors achieve annual losses resulting from their operations.

b. Investment expenses. The Government of Jordan considers attracting local and foreign private investments as one of the objectives of the privatization process (National Privatization Strategy, 1999, p. 7). Thus, privatization is assumed to lead to the privatization of the private sector, To reduce the volume of investment 
expenditure of the state, and the financing expenses incurred thereby reducing the financial burden of the public budget.

\subsubsection{Requirements for Achieving Privatization Programs for Their Objectives}

The success of privatization programs depends on the availability of the following elements (Lutfi, 2010):

a. Providing new legislative frameworks necessary to ensure a shift towards capitalism.

b. Restructuring the administrative system to cope with the new reality.

c. Establishing the administrative policies necessary for the adoption of a marketing program and promotion of companies to be privatized.

d. The need for a gradual approach to the implementation of the program because of its positive and effective effects.

e. Taking the environmental dimension into consideration when assessing the performance of privatized companies.

f. Improvement of infrastructure as the main pillar of the success of the privatization program to ensure the pace of technological progress.

It should be noted here concerning the availability of the legislative framework of the Privatization Program in Jordan that the program started virtually in 1998, and there was no special legislation to regulate privatization and set its objectives, mechanisms and means of exploiting its revenues. The situation continued until the issuance of Privatization Law in mid-2000. Article 20 provides that the Council of Ministers shall issue the necessary regulations to implement the provisions of the Law. The implementation of Privatization Law No. 80 was issued in 2008, the year in which the last privatization operation took place, eight years after the issuance of the Law.

\subsubsection{The Final Account of the State}

The final account in the government sector is the result of the implementation of the general budget deficit or surplus for the financial period ending on the date set by the final account, which is similar to the list of the result of business in the private sector where the financial report reflects the amounts that the government units actually received or paid compared to the provisions allocated to them for their expenditures or the amount of revenue to collect them in the general budget, therefore, it is defined as "a document containing the financial and explanatory statements of the actual expenses and revenues collected for the fiscal year ended in comparison with the budget appropriations" and is of great importance because it is used by the executive and supervisory bodies for the following purposes (Ismail \& Adas, 2009):

a. To assess the commitment of government accounting units to implement financial laws, including the General Budget Law.

b. To follow up the implementation of the general budget plan and its activities and policies.

c. To identify the appropriateness of methods of estimating revenues and expenditures and improve them to reach the nearest numbers to be accurate.

d. To identify the encroachments that has been made in the allocations.

The purpose of identifying the encroachment on allocations is one of the most important goals served by the final account, as exceeding the allocations is considered one of the crimes punishable by law in most countries of the world. The Jordanian Constitution and the laws and regulations governing the management of the state's financial affairs include provisions that criminalize this conduct (The Jordanian Constitution, Articles 111-119).

\subsection{Previous Studies}

A study conducted by Qandah (2003) entitled: Privatization, the latest models of economic development. The purpose of this study was to assess Jordan's experience in privatization, which dealt with the legislative and institutional framework of the process, the methods of privatization followed, the basis for its selection, the regulatory frameworks for the sectors subject to privatization, the primary effects of privatization on the macroeconomic and microeconomic variables and the uses of privatization revenues, privatization and social safety net, The study pointed out that due to the lack of data on the revenues generated from the various projects that were privatized, the data of the telecom company were used as an example of Companies that have been privatized, and the data suggest this company to increase government revenues from taxes paid by the company after privatization, compared with what it was before privatization. 
The study of Awawleh (2004) entitled "The Effect of Privatization of Public Sector Enterprises on Public Budget in Jordan". This study was conducted in Jordan with the aim of identifying the feasibility and analysis of economic and financial reform policy in the privatization of public sector institutions in Jordan, and the impact of the privatization of public sector institutions and companies on the state budget in Jordan in terms of revenues and expenditures and achieving financial savings, and the impact of this is the size of the public debt.

The study sample was composed of four companies and public institutions namely Public Transport Corporation, Telecommunications Companies, Cement Factories and Maeen Baths Resort. The study used the descriptive survey method; the study found that it is not necessary for privatization to increase government revenues. The study found that the government revenues decreased in four of the study sample and increased in one only. As for the expenditure, privatization led to a decrease in expenditure in two companies and an increase in two companies from the sample of the study. The study found that the privatization did not lead to financial savings for the government of companies and institutions that have been privatized.

The study of (Executive Body for privatization, 2006) entitled " The Impact of Privatization in Jordan". The objective of this study is to assess the level of achievement achieved by the Privatization Program in relation to each of the policies adopted by the Government, which is to raise the level of productive efficiency at a competitive level, increase private investment in infrastructure, attract local investments, develop the local capital market and support the state treasury and eased the debt burden on the treasury, the management of economic projects in modern ways, stability and high levels of employment, achieving sound financial results and increasing revenues after privatization while ensuring commercially viable operations. The study included the privatizations carried out during the period 2001-2005),the descriptive method was used to assess the impact of privatization at the project, sector and national levels, the study found that privatization objectives were largely achieved due to the existence of an appropriate macroeconomic and business environment, and the transfer of technology related to the operations, with regard to the goal of reducing the financial burden on the state treasury, the study pointed to "The government of Jordan has been exempted from the burden of financial havoc caused by the city's losing companies," she said in an assessment of the impact of privatization on public finances of the state. "The privatization program allowed for the elimination of government support to a number of losing companies, and to impose taxes and duties on privatized companies.

Christen and Kogur (2009) conducted a study entitled "The Impact of Restructuring and Privatization of Public Institutions in the Infrastructure and Other Sectors in Jordan (1994-2008). This study examines the motives of restructuring and privatization that took place during the period 1994-2008 and the direct impact of these operations on the parties involved in the privatization process, namely consumers, employees, workers, privatized enterprises and local communities, and on the national economy in terms of investments, labor, financial markets and competitiveness, and on the public treasury.The study concluded that privatization had a positive effect on all the above evaluation axes except for owners and operators. The study indicated that they achieved modest gains, the study also pointed out that the privatization process had a positive effect on the general treasury through the privatization proceeds which were transferred to the treasury amounting to (1.73) billionJD, in addition to the recurrent financial contributions from privatized institutions.

Lotfi (2010) conducted a study entitled Privatization Programs in the Arab World.This study is an analytical study of Privatization programs in the Arab World. The study dealt with the experiences of all Arab countries and pointed out that the majority of the Arab countries that implemented privatization programs were at the request of the countries and the international creditors. It dealt with the Jordanian experience in terms of concepts, objectives, general principles, methods, implementation priorities, uses of privatization proceeds, the study showed that privatization revenues are the price of assets accumulated over time and should therefore be used wisely and rationally to benefit the national economy. This use should be based on clear and specific principles and priorities, including dealing with employees of privatized institutions and companies,enabling the government to repay debts it bear on behalf of privatized public institutions, to finance new investments in the infrastructure and social sectors that the private sector cannot do.

Al-Jundi (2015) conducted a study entitled: The impact of privatization on the financial and operational performance of privatized companies and on the state budget in Jordan.The study aimed at identifying the impact of privatization on the financial and operational performance of the privatized companies and on the general budget of the State in Jordan. The study included the privatization operations that took place during the period 2000-2008. The study consisted of two main parts. The first is to assess the impact of privatization on the financial and operational performance of companies which was privatized after the issuance of the Privatization Law in 2000 by comparing the financial and operational performance indicators of these companies for five years before privatization and five years later,the study also included assessing the effect of privatization on the 
general budget of the state, the public debt burden of the state and the size of public debt service burden by comparing the percentage of deficit in the general budget and the growth rate of public debt and the size of the burden of public debt service to the size of the general budget for a period of five years before the issuance of the privatization law i.e. the period 1995-2005. The study concluded that privatization led to an improvement in the profitability of the privatized companies and in their operational performance, but did not affect the percentage of the general budget deficit, the size of the general indebtedness of the state or the size of the public debt service burden.

Katsoulakos and Likoynni (2002) conducted a study entitled "Fiscal and other macroeconomic effect of privatization", the objective of this study was to investigate the effect of privatization on the deficit of the general budget, the size of public debt and some macroeconomic variables such as unemployment and economic growth. The study included the data of twenty-three member countries of the Organization for Economic Cooperation and Development (OECD) for the period 1990-2000,the study pointed out that the impact of privatization on the public budget could be through increasing government revenues from privatized companies and reducing government subsidies to government sector companies. More specifically, the study showed that privatization has a positive and lasting effect on tax revenues in countries that are not undergoing a transformation in their economic systems; the study used a less squares model to find the relationship between privatization returns and the general budget deficit. It was found that there is no statistically significant relationship between the privatization revenues and the general budget deficit in the countries that represent the sample of the study.

Sheshinski and Lopez- Calva (2003) conducted a study entitled "Privatization and its benefits, theory and evidence", this study was conducted in Switzerland in 2003 and reviewed the theoretical basis of the privatization process, there are two types of studies on the impact of privatization. The first type is carried out at the micro level, i.e. the extent of privatization influence on the financial and operational performance of privatized institutions or companies. The second is conducted at the level of macroeconomic variables such as the state budget, economic growth, unemployment and others. This study aimed to test a set of hypotheses related to the expected objectives of privatization at the macro and micro levels and concluded that privatization led to the reduction of the cumulative support provided by the government to the companies it owned, and this support could turn into cash flows for the government if the government began to collect taxes from privatized companies, it also showed that the budget deficit in countries that have implemented privatization programs showed a positive trend, a decrease during the transition phase, although the countries that are going through this stage are still suffering from their budgets deficit.

Mansour (2006) conducted a study entitled "The budgetary impact of privatization". The study aimed to review the prevailing understanding that the sale of government to the companies owned by them improves the budget of these governments. The study pointed out that despite the improvement in the traditional deficit in the budgets of countries that implement privatization programs in the short term, there will be no positive effect of privatization on the public budgets of these countries in the long term because this requires a real improvement in efficiency and this requires encouraging competition and increasing reliance on market forces, the study concluded that privatization should focus on the sale of assets with low returns, which constitute the main monopolies of governments. Governments should prepare to confront the concentration of private investments through investment in infrastructure or human capital, and not to use privatization proceeds to finance public or private consumption, but must be directed towards the investments of foreign investments.

Kibikyo (2008) conducted a study entitled "Fiscal impact of privatization in Uganda, 1992-2002". This study aimed at examining the financial impact of privatization in Uganda by looking at the subsidy provided by the government to privatized companies as government expenditure, the taxes obtained by the government from these companies and the proceeds of privatization as revenues. The study showed that the value of government subsidies did not change in nominal value for the period 1992- 2005, and that there was no correlation between the value of support and the budget of the central government, where it appears that the increase in the deficit in the general budget is not the result of government support for privatized companies, but for other factors, including tax collections, as for revenue from privatized companies has increased fourfold because of the increased activity of these companies. The study also showed that governments failed to obtain the World Bank's estimated privatization returns.

Sunderland (2011) conducted a study entitled "Fiscal impact of privatization in developing countries". The aim of this study was to determine the impact of privatization on the budgets of countries that implemented privatization programs. The study sample consisted of 47 developing countries, the study depended on World Bank data on privatization returns for the years 1988-2008 and used the multiple regression model to find the relationship between the independent variable, the privatization returns and the dependent variable the public 
budget deficit, the study found that none of the variables included in the model can explain the change in the general budget deficit, because the model suffers from the omission of some factors that may affect the dependent variable. When the study was conducted to impose the stability of other factors that can affect the general budget in a particular country over time, the study found that a different result of the findings of some previous studies is that there is a negative relationship and statistically significant between the proceeds of privatization and the deficit of public budget.

Yar.et al, (2013) conducted a study entitled "Privatization and fiscal deficit: A case study of Pakistan" this study dealt with the Pakistani experience in privatization in terms of objectives, size and distribution of revenues, the study pointed out that the budget deficit is not only an economic problem, but also for decision makers in the world where the increase in government expenditure on revenues leads to problems of economic performance, the budget deficit represents the difference between government expenditures and government revenues for a certain period, often one year, and Pakistan was unable to manage the difference between government revenues and expenditures, which made the budget deficit a major problem for the Pakistani economy. The study pointed out that there are two approaches to study the impact of privatization, Trend Analysis and Theoretical model, the study used the first model using the data of twenty-two years, eleven years before privatization, and eleven years after. The study concluded that privatization in Pakistan did not lead to the achievement of its primary objective which is to reduce the fiscal deficit in the public budget by reducing the gap between expenditures and government revenues.

\subsubsection{What Distinguishes This Study from Previous Studies}

This study is characterized by the following:

- The study depended on the actual data of government expenditure and revenues, not on what is estimated at the beginning of the fiscal year under the general budget estimates.

- The study analyzed the structural changes that were made to the components of the general budget, which are the general revenues, their components, the general expenses and their components, and did not rely on studying the deficit in the budget.

- The study included a period of twenty-one years, a longer time frame than any other study, according to the researcher's knowledge

\section{Method and Procedures}

\subsection{Research Methodology}

To assess the effect of privatization on the final account of the state, the revenue aspect was analyzed according to its basic components: local revenues, grants and installments of the recovered loans, and then finding their proportion to the size of the general budget for ten years before the privatization year (1990-1999) and ten years after the privatization year (2001-2010). The year 2000 was excluded from the comparison as the year in which the privatization law was issued; this is the official beginning of the implementation of the program. The expenditures in the final account were also carried out to its main components, current expenditures and investment expenditures annually, and the ratio of each to the size of the general budget for ten years before the privatization year (1990-1999) and ten years after the privatization year 2001-2010), with the exception of the privatization year from the comparison for the reason mentioned above, then the descriptive statistics for each of the percentages above were carried out for the two periods before privatization and then the preparation of the appropriate statistical test to determine the existence of significant differences between these ratios before and after implementation of the Privatization Program.

\subsection{Population and Sample of the Study}

The study population consists of all the financial years that the researcher was able to obtain the final accounts for them, either before or after privatization, and include the years (1982-2015). The sample of the study included twenty years, divided into two sub-samples, the first sub-sample consisting of ten years before the start Implementation of the Privatization Program, which began in 2000, i.e. the period (1990-1999), the second sub-sample, consisting of ten years after the implementation of the Privatization Program (2001-2010), was chosen purposefully because the more the years away from the privatization year, the greater the influence of other factors that could affect the final account and the independent variable of the study which is privatization.

\subsection{Data Sources}

The data of the study were obtained from its primary sources, which are represented in the publications and reports of the Ministry of Finance and the Public Budget Department, where a summary of the final account is 
published annually in the Public Finance Bulletin issued by the Ministry of Finance, and some secondary sources such as electronic websites were used to obtain some data that could not be obtained from its main sources.

\subsection{Study Variables}

Independent variable: it is implementing privatization program, the study assumes that the government privatization of the service sectors and the companies that it owned or contributed to them affect the variables of the study. The government is supposed to privatize the sectors and companies that are a financial burden on its budget, therefore, the privatization of these sectors and companies is expected to lead to a decrease in the volume of public expenditure, it is also assumed that in the event of achieving privatization in order to raise the financial and operational efficiency of the privatized companies, the tax revenues of the state will increase from these companies and thus increase their public revenues.

\subsection{Dependent Variables}

a. Local Revenue: Local revenues are affected by privatization in two ways. First, in the short term, as privatization revenues can be considered as local revenues for the budget and thus used to cover some types of expenditures in the general budget. The government also receives revenues from the use of some privatized facilities, license fees and fees from service sectors which has been privatized, and second, in the medium and long term, privatization is supposed to increase the profitability of privatized companies, thereby increasing the government's tax revenues accordingly.

b. Grants: Privatization is supposed to increase in size of profitability because privatization approaches make creditor countries offer more grants to encourage countries that implement privatization programs to move ahead with their programs, helping them repay their debts.

c. Repayment of recovered loans. Privatization is supposed to increase the ability of the state to service its debts, i.e. repaying the benefits and premiums of loans and interest on due dates and discontinuing scheduling, thereby reducing its revenue from loan repayments.

d. Current expenditure: Privatization is supposed to reduce the current expenditure of countries that implement privatization programs, considering that these countries will resort to the privatization of companies and sectors that are a financial burden on their budgets first, and then the rest of the companies and sectors.

e. Investment expenses: Privatization is supposed to lead to a decrease in the volume of investment expenditures of the state as a result of the elimination of the burden of investment spending for sectors and privatized companies.

Table (1) below presents data on government revenues for the pre-privatization and post-privatization periods and table 2 for government expenditure for the pre-privatization and post-privatization periods.

Table 1. Values and proportions of the components of public revenues to the size of the general budget $\left(^{*}\right)$ million dinars

\begin{tabular}{|c|c|c|c|c|c|c|c|}
\hline Year & Budget size & $\begin{array}{l}\text { The size of } \\
\text { local } \\
\text { revenue }\end{array}$ & $\begin{array}{l}\% \text { The size of } \\
\text { local revenue / } \\
\text { budget }\end{array}$ & $\begin{array}{l}\text { The size } \\
\text { of grants }\end{array}$ & $\begin{array}{l}\text { \% Size of } \\
\text { the } \\
\text { grants / } \\
\text { budget }\end{array}$ & $\begin{array}{l}\text { size of loan } \\
\text { installments }\end{array}$ & $\begin{array}{l}\% \text { size of loan } \\
\text { installments/ } \\
\text { budget }\end{array}$ \\
\hline 1990 & 1032.64 & 744.06 & 72.05 & 164.28 & 15.91 & 29.86 & 2.89 \\
\hline 1991 & $1117.05^{* *}$ & 828.78 & 74.19 & 230.25 & 20.6 & 58.02 & 5.19 \\
\hline 1992 & $1358.72 * *$ & 1168.92 & 86.03 & 137.42 & 1.11 & 52.39 & 3.85 \\
\hline 1993 & $1406.30 * *$ & 1141.96 & 84.72 & 163.29 & 11.61 & 51.55 & 3.66 \\
\hline 1994 & $1537.33 * *$ & 1306.39 & 84.98 & 175.55 & 11.42 & 55.4 & 3.6 \\
\hline 1995 & $1619.98^{* *}$ & 1389.12 & 85.75 & 182.76 & 11.28 & 48.09 & 2.97 \\
\hline 1996 & $1723.22 * *$ & 1430.06 & 82.99 & 247.01 & 14.33 & 46.15 & 2.68 \\
\hline 1997 & 1884.19 & 1369.9 & 72.70 & 205.0 & 10.88 & 45.93 & 2.43 \\
\hline 1998 & 2028.71 & 1496.53 & 73.77 & 172.22 & 8.49 & 32.63 & 1.61 \\
\hline 1999 & 1956.25 & 1585.28 & 81.04 & 198.54 & 10.15 & 32.12 & 1.64 \\
\hline 2000 & Start implementing & Program & Privatization & & & & \\
\hline 2001 & 2123.5 & 1638.04 & 77.14 & 249.4 & 11.74 & 80.56 & 3.79 \\
\hline 2002 & 2221.95 & 1676.71 & 75.46 & 266.67 & 12.00 & 73.32 & 3.3 \\
\hline 2003 & 2442.42 & 1631.52 & 66.8 & 687.85 & 28.16 & 44.04 & 1.8 \\
\hline
\end{tabular}




\begin{tabular}{|c|c|c|c|c|c|c|c|}
\hline 2004 & 2931.03 & 2087.57 & 71.12 & 667.05 & 22.75 & 59.66 & 2.03 \\
\hline 2005 & 3104.51 & 2523.23 & 81.28 & 501.08 & 16.14 & 39.72 & 1.28 \\
\hline 2006 & 3860.44 & 3120.51 & 80.83 & 304.6 & 7.9 & 43.88 & 1.14 \\
\hline 2007 & 4540.05 & 3576.7 & 78.58 & 343.39 & 7.56 & 51.39 & 1.13 \\
\hline 2008 & 5431.93 & 4327.17 & 79.7 & 718.34 & 13.22 & 48.18 & 8.87 \\
\hline 2009 & 6030.5 & 4142.27 & 68.69 & 333.38 & 5.52 & 45.16 & 0.75 \\
\hline 2010 & 5708.0 & 4219.63 & 73.92 & 401.79 & 7.04 & 41.38 & 0.72 \\
\hline
\end{tabular}

* Prepared by the researcher from the data of the Ministry of Finance and the General Budget Department

** Budget size for this year is the size of public revenues

Table 2. Values and percentages of public expenditures to the size of the general budget $(*)$ million dinars

\begin{tabular}{|c|c|c|c|c|c|}
\hline Year & $\begin{array}{l}\text { Budget } \\
\text { size }\end{array}$ & $\begin{array}{l}\text { The size of current } \\
\text { expenditures }\end{array}$ & $\begin{array}{l}\text { \% Current expenditure } \\
\text { / budget size }\end{array}$ & $\begin{array}{l}\text { Volume of } \\
\text { investment expenses }\end{array}$ & $\begin{array}{l}\% \text { Investment expenditure / size } \\
\text { of the general budget }\end{array}$ \\
\hline 1990 & 1032.64 & 841.38 & 81.47 & 191.26 & 18.52 \\
\hline 1991 & $1117.05 * *$ & 904.0 & 82.92 & 195.62 & 17.51 \\
\hline 1992 & $1358.72 * *$ & 938.52 & 69.07 & 352.72 & 25.96 \\
\hline 1993 & $1406.30 * *$ & 1044.29 & 74.25 & 292.29 & 21.53 \\
\hline 1994 & $1537.33 * *$ & 1116.46 & 72.26 & 376.23 & 24.52 \\
\hline 1995 & $1619.98 * *$ & 1220.43 & 75.37 & 384.4 & 23.73 \\
\hline 1996 & $1723.22 * *$ & 1296.83 & 75.23 & 410.24 & 23.81 \\
\hline 1997 & 1884.19 & 1457.0 & 77.33 & 427.19 & 22.67 \\
\hline 1998 & 2028.71 & 1585.85 & 78.17 & 443.18 & 21.84 \\
\hline 1999 & 1956.25 & 1559.88 & 79.73 & 396.37 & 20.26 \\
\hline 2000 & \multicolumn{5}{|c|}{ Start the implementation of the privatization program } \\
\hline 2001 & 2123.5 & 1719.68 & 80.98 & 403.81 & 19.02 \\
\hline 2002 & 2221.95 & 1783.09 & 80.24 & 438.36 & 19.76 \\
\hline 2003 & 2442.42 & 1975.4 & 80.88 & 467.01 & 19.12 \\
\hline 2004 & 2931.03 & 2309.93 & 78.81 & 621.1 & 21.19 \\
\hline 2005 & 3104.51 & 2469.79 & 79.55 & 634.71 & 20.45 \\
\hline 2006 & 3860.44 & 3066.31 & 79.43 & 794.12 & 20.57 \\
\hline 2007 & 4540.05 & 3697.43 & 81.43 & 842.62 & 18.56 \\
\hline 2008 & 5431.93 & 4473.4 & 82.35 & 958.51 & 17.65 \\
\hline 2009 & 6030.5 & 4586.03 & 67.05 & 1444.56 & 23.95 \\
\hline 2010 & 5708.0 & 4746.6 & 83.16 & 961.42 & 16.84 \\
\hline
\end{tabular}

* Prepared by the researchers from the data of the Ministry of Finance.

** The size of the budget for this year is the size of public revenues.

\subsection{Statistical Method}

This study investigates its dependent variables on a sample of the years that were selected purposefully for the years (1990-2010). To achieve the objectives of the study, the sample of the study was divided into two sub-samples: the first sub-sample represents the pre-start period of the independent variable effect (implementation of the privatization program), and the second sub-sample represents the period after the effect of the independent variable (privatization program implementation) on these variables, i.e., the comparison between the behavior of the same variables during two time periods (two samples). Thus, the concept of independent samples applies (Al-Atoum and Aruri, 2000), in this case, the (Independent Sample t-Test) is used to measure the extent of differences in the mean of two groups or two independent samples for a variable (Sekaran, 1992). This test was used in this study after implementing (K-s) to test the normal distribution of the financial ratios under study and table (3) shows the values of the torsion coefficient and the results of the (k-s) tests to test the normal distribution of the financial ratios under study. 
Table 3. Results of the (k-s) tests to test the distribution of study data

\begin{tabular}{|c|c|c|c|c|}
\hline \multirow[t]{2}{*}{ Financial Ratios $(*)$} & \multirow[t]{2}{*}{$\mathbf{N}$} & \multirow[t]{2}{*}{ Torsion coefficient } & \multicolumn{2}{|l|}{$k-s$ test } \\
\hline & & & $\mathrm{k}-\mathrm{s}$ value & Sig \\
\hline Local Revenue & 20 & -0.048 & .186 & .070 \\
\hline Percentage of grants obtained by the State & 20 & 1.356 & .176 & .106 \\
\hline Ratio of loans recovered by the State & 20 & 0.660 & .132 & .200 \\
\hline Percentage of current state expenditure in Jordan & 20 & 0.511 & .124 & .200 \\
\hline Percentage of investment expenditure of the State in Jordan & 20 & 0.282 & .078 & .200 \\
\hline
\end{tabular}

(*) Ratio to the size of the state budget

The table above shows that the values of torsion coefficients ranged from $(-0.048)$ to local income ratios and (1.356) to the ratios of grants obtained by the state. These values fall within the range in which the values of torsion coefficients are accepted by studies if it is restricted between $(-3$ and +3$)$ and some studies accept it if it is restricted between $(-1$ to +1$)$. The table above shows that the values of the significance of the $(\mathrm{k}-\mathrm{s})$ test for all the percentages shown in the table were greater than $(\alpha \leq 0.05)$, which means that there are no statistically significant differences between normal distribution and distribution of the data of these ratios means coupling of the current ratios data in this study of normal distribution and thus the possibility of applying the cognitive tests such as (t) test.

\section{Statistical Analysis and Display of the Results}

\subsection{Descriptive Statistics}

Table 4 shows the results of the descriptive analysis of the financial ratios under study related to the size of the general budget of the State in Jordan during the whole study period. Table (5) below shows the average financial ratios under study for the entire study period, the pre and post privatization period, and the change that occurred in these percentages after the implementation of the privatization program.

Table 4. Values of descriptive statistics of the financial ratios under study (\%) *

\begin{tabular}{|c|c|c|c|c|c|}
\hline Financial Ratios $(* *)$ & $\mathbf{N}$ & Minimum value & Maximum value & Mean & Standard deviation \\
\hline Percentage of grants awarded by the State & 20 & 5.528 & 29.104 & 13.347 & 5.910 \\
\hline Ratio of loans recovered by the State & 20 & 0.725 & 5.747 & 2.474 & 1.347 \\
\hline Percentage of current state expenditure in Jordan & 20 & 72.684 & 93.100 & 81.4 ९03 & 5.613 \\
\hline $\begin{array}{l}\text { Percentage of investment expenditure of the State in } \\
\text { Jordan }\end{array}$ & 20 & 16.843 & 27.316 & 21.605 & 2.549 \\
\hline
\end{tabular}

(*) Prepared by the researchers based on data from the Ministry of Finance

(**) relative to the size of the state budget

Table 5. Comparison of the computational mean of the financial ratios under study $(\%) *$

\begin{tabular}{|c|c|c|c|c|}
\hline Financial Ratios $(* *)$ & $\begin{array}{l}\text { Full study } \\
\text { period }\end{array}$ & $\begin{array}{l}\text { Pre-privatization } \\
\text { period }\end{array}$ & $\begin{array}{l}\text { Post-privatization } \\
\text { period }\end{array}$ & $\begin{array}{l}\text { The difference between pre } \\
\text { and post privatization }\end{array}$ \\
\hline $\begin{array}{l}\text { Percentage of grants obtained } \\
\text { by the State }\end{array}$ & 13.347 & 12.871 & 13.822 & -0.951 \\
\hline $\begin{array}{l}\text { Ratios of recovered loans } \\
\text { received by the state }\end{array}$ & 2.474 & 3.165 & 1.783 & 1.382 \\
\hline $\begin{array}{l}\text { Ratios of current expenditures } \\
\text { of the state in Jordan }\end{array}$ & 81.403 & 78.387 & 84.418 & -6.031 \\
\hline $\begin{array}{l}\text { Ratios of investment expenses } \\
\text { of the state in Jordan }\end{array}$ & 21.605 & 22.506 & 20.705 & 1.801 \\
\hline
\end{tabular}

Table 4 shows the values of the descriptive statistics of the financial ratios under study due to the size of the state budget in Jordan for the whole period of study. These percentages were found to be between $(68.689 \%)$ and 
$(90.527 \%)$ to the ratios of domestic income, where the value of the arithmetic average of this ratio reached $(80.150 \%)$. The table also shows that the percentage of grants received by the State in Jordan during the period before and after privatization was between $(5.528 \%)$ and $(29.104 \%)$ with an average of $(13.347 \%)$, with regard to the ratios of loans obtained by the State, ranged from $(0.725 \%)$ and $(5.747 \%)$. The average value of this ratio was $(2.474 \%)$, with regard to the proportions of current expenditures of the state in Jordan, before and after the period of privatization ranged between $(72.684 \%)$ and $(93.100 \%)$ as the value of the arithmetic mean of this percentage was $(81.403 \%)$

As for the percentage of the investment expenditure of the state in Jordan, it ranged from (16.843\%) and $(27.316 \%)$, where the mean of the arithmetic mean of this ratio $(21.605 \%)$. By comparing the ratios shown in Table (5) it is clear that the average rates of domestic revenue, and recovered loans, and pre-privatization investment expenditures were greater than for the post-privatization period. The average ratios of grants received by the State and current expenditures were during the pre-privatization period less than for the post-privatization period. The subsequent chapter shows the results of an examination of whether these differences are statistically significant or not.

1. Analytical Statistics and Results of hypothesis testing

a. The first main hypothesis (HO1): There are no statistically significant differences between the ratios of the local revenues of the state in Jordan to the size of the state budget before and after the implementation of the privatization program at a significant level $(\alpha \leq 0.05)$.

To verify this hypothesis, the t-test of the independent samples was used to compare the average local revenue ratios of the state in Jordan to the size of the state budget before and after implementation of the privatization program. The results of this hypothesis are shown in the following table.

Table 6. Results of the t-test of the difference between the average local revenues of the state in Jordan and the size of the state budget before and after the implementation of the privatization program

\begin{tabular}{|c|c|c|c|c|c|c|c|}
\hline The ratio & Period & $\mathbf{N}$ & Mean & $\begin{array}{l}\text { Standard } \\
\text { deviation }\end{array}$ & T value & Sig & Decision \\
\hline \multirow[t]{2}{*}{$\begin{array}{l}\text { Local revenues of the state in } \\
\text { Jordan }\end{array}$} & $\begin{array}{l}\text { Before } \\
\text { privatization }\end{array}$ & 10 & 81.919 & 6.929 & 1.05 & 0.307 & Acceptance \\
\hline & $\begin{array}{l}\text { After } \\
\text { privatization }\end{array}$ & 10 & 78.381 & 8.086 & & & \\
\hline
\end{tabular}

The table above shows that the value of calculated $(\mathrm{t})$ for the difference between the average of the local revenue rates of the state in Jordan before and after privatization was (1.05) at the level of significance (0.307) and since the value of the significance level was greater than $(\alpha \leq 0.05)$ this indicates that there are no significant differences between the ratio of the local revenues of the state in Jordan prior to privatization and after it, i.e., the differences between the two averages is not considered a statistically significant indicator and by this result the null hypothesis which is the hypothesis of the study is accepted.

b. The second main hypothesis (HO2): There are no statistically significant differences between the ratios of grants obtained by the state in Jordan to the size of the general budget of the state before and after implementation of privatization program at a significant level $(\alpha \leq 0.05)$.

To verify this hypothesis, the t-test of the independent samples was used to compare the average rates of grants obtained by the state in Jordan to the size of the state budget before and after implementation of the Privatization Program. The following table shows the results of this hypothesis.

Table 7. Results of the t-test for the difference between the average percentages of grants received by the State in Jordan and the size of the general state budget before and after implementation of the Privatization Program

\begin{tabular}{|c|c|c|c|c|c|c|c|}
\hline Ratio & Period & $\mathbf{N}$ & Mean & $\begin{array}{l}\text { Standard } \\
\text { deviation }\end{array}$ & T value & Sig & Decision \\
\hline \multirow[t]{2}{*}{$\begin{array}{l}\text { Grants received by the State in } \\
\text { Jordan }\end{array}$} & $\begin{array}{l}\text { Before } \\
\text { privatization }\end{array}$ & 10 & 12.871 & 4.081 & 0.35 & 0.729 & Acceptance \\
\hline & $\begin{array}{l}\text { After } \\
\text { privatization }\end{array}$ & 10 & 13.822 & 7.523 & & & \\
\hline
\end{tabular}


The table above shows that the value of calculated $(\mathrm{t})$ for the difference between the average rates of grants obtained by the state in Jordan before and after privatization was $(0.35)$ at the level of significance $(0.729)$. Since the value of the significance level was greater than $(\alpha \leq 0.05)$, this indicates that there are no statistical significance differences between the average rates of grants obtained by the State in Jordan before and after privatization, that the differences between the average ratios is not considered essential or important statistical indicator and by this result the null hypothesis of the study is accepted.

c. The third main hypothesis (HO3): There are no statistically significant differences between the percentage of loans recovered by the state in Jordan to the size of the general budget of the state before and after the implementation of privatization program at a significant level $(\alpha \leq 0.05)$.

To verify this hypothesis, the t-test of the independent samples was used to compare the average rates of loans recovered by the state in Jordan to the size of the state budget before and after the implementation of the Privatization Program. The results of this hypothesis are shown in the following table.

Table 8. The results of the t-test of the difference between the average rates of recovered loans obtained by the State in Jordan and the size of the general state budget before and after the implementation of the Privatization Program

\begin{tabular}{llllllll}
\hline Ratio & Period & N & Mean & Standard deviation & $\begin{array}{l}\text { T } \\
\text { value }\end{array}$ & Sig & Decision \\
\hline $\begin{array}{l}\text { Percentage of loans recovered by the State } \\
\text { in Jordan }\end{array}$ & $\begin{array}{l}\text { Before } \\
\text { privatization }\end{array}$ & 10 & 3.165 & 1.239 & 2.62 & 0.017 & Rejection \\
& After privatization & 10 & 1.783 & 1.111 & & \\
\hline
\end{tabular}

The table above shows that the value of calculated $(\mathrm{t})$ for the difference between the average rates of recovered loans obtained by the state in Jordan before and after privatization was (2.62) at the level of (0.017). Since the value of the significance level was less than (0.05), this indicates that there are statistically significant differences between the average ratios of recovered loans obtained by the State in Jordan before and after privatization, i.e. the differences between the average ratios is considered to be significant or statistically important indicator. The differences between the two averages tend to be in favor of the pre-privatization period, the value of the arithmetic average for this period was higher than the average of the post-privatization period, and by this result the null hypothesis, which is the hypothesis of the study, is rejected and the alternative hypothesis is accepted.

d. The fourth main hypothesis (HO4): There are no statistically significant differences between the ratios of the current expenditure of the state in Jordan to the size of the state budget before and after implementation of the privatization program at a significant level $(\alpha=0.05)$.

To verify this hypothesis, the t-test of independent samples was used to compare the average current expenditure ratios of the state in Jordan to the size of the state budget before and after privatization. The following table shows the results of this hypothesis.

Table 9. Results of the t-test for the difference between the average current expenditure rates of the state in Jordan and the size of the state budget before and after implementation of the Privatization Program

\begin{tabular}{|c|c|c|c|c|c|c|c|c|}
\hline Ratio & & Period & $\mathbf{N}$ & Mean & $\begin{array}{l}\text { Standard } \\
\text { deviation }\end{array}$ & T value & Sig & Decision \\
\hline \multirow{2}{*}{\multicolumn{2}{|c|}{$\begin{array}{l}\text { Percentage of current } \\
\text { expenditure in Jordan }\end{array}$}} & $\begin{array}{l}\text { Before } \\
\text { privatization }\end{array}$ & 10 & 78.387 & 4.640 & 2.80 & 0.012 & Rejection \\
\hline & & $\begin{array}{l}\text { After } \\
\text { privatization }\end{array}$ & 10 & 84.418 & 4.977 & & & \\
\hline
\end{tabular}

The table shows that the value of calculated $(\mathrm{t})$ for the difference between the average of current expenditure rates of the state in Jordan before and after privatization reached (2.80) at the level of significance (0.012) and since the value of the significance level was less than $(0.05)$, this indicates that there are statistically significant differences between the average ratios of the current expenditure of the state in Jordan before and after privatization, i.e. the differences between the two averages is considered to be a significant or statistically 
significant indicator, and the differences between the two averages were in favor of the post-privatization period. The value of the arithmetic average for this period increased more than the pre-privatization period as shown in the table above, by this result the null hypothesis which is the study hypothesis is rejected and the alternative hypothesis is accepted which is the presence of the difference.

e. The fifth main hypothesis (HO5): There are no statistically significant differences between the ratios of the investment expenditure of the state in Jordan to the size of the state budget before and after the implementation of the privatization program at a significant level $(\alpha=0.05)$.

To verify this hypothesis, the t-test of independent samples was used to compare the average ratios of the state's investment expenditure in Jordan to the size of the state budget before and after implementation of the privatization program. The following table shows the results of this hypothesis

Table 10. Results of t-test for the difference between the average ratios of the state's investment expenditure in Jordan to the size of the state's general budget before and after implementation of the privatization program

\begin{tabular}{llllllll}
\hline Ratio & Period & N & Mean & $\begin{array}{l}\text { Standard } \\
\text { deviation }\end{array}$ & T value & Sig & Decision \\
\hline $\begin{array}{l}\text { Ratios of investment expenditure of } \\
\text { the state in Jordan }\end{array}$ & $\begin{array}{l}\text { Before } \\
\text { privatization } \\
\text { After } \\
\text { privatization }\end{array}$ & 10 & 22.506 & 2.717 & 1.65 & 0.116 & Acceptance \\
& & & 20.705 & 2.129 & & & \\
& & & & & & & \\
\hline
\end{tabular}

The table above shows that the value of calculated $(t)$ for the difference between the average ratios of the investment expenditure of the state in Jordan before and after privatization reached (1.65) at the level of significance (0.116) and since the value of the significance level was greater than $(0.05)$ this indicates that there are no statistically significant differences between the ratio of the investment expenditure of the State in Jordan before and after privatization, i.e., the differences between the two averages are not considered a significant or important statistical indicator, and by this result the null hypothesis which is the hypothesis of the study is accepted.

\section{Conclusions and Recommendations}

\subsection{Conclusions}

The study reached the following results:

a. The implementation of privatization program in Jordan did not affect the ratio of local revenues to the size of the general budget of the state, where the average of this percentage before privatization was $(81.919 \%)$ and after the privatization $(78.381 \%)$, i.e. the contribution of local revenues in financing the budget decreased by (3.538\%) after privatization, but this effect is not considered statistically significant, this result is contrary to the study of (Christen and Gokgur, 2009), which indicated that the Privatization Program in Jordan had a significant positive effect on the state treasury, either through one-time privatization proceeds or recurrent financial contributions from privatized institutions, as well as the study of Qandah (2003), but it is consistent with the findings of the study of (Awaqleh, 2004), which indicated that government revenues from privatized companies had declined in four of the five cases studied.

b. The implementation of privatization program in Jordan did not affect the percentage of grants obtained by the state to the size of the general budget of the state. The average of this percentage before privatization was $(12.871 \%)$ and increased after privatization to $(13.822 \%)$, an increase of $(0.951 \%)$, but these are not statistically significant, and this result is contrary to expectations from the privatization program.

c. The implementation of the program led to a decrease in the ratio of loans recovered by the state to the total general budget. The rate of implementation before the implementation of the privatization program was $(3.165 \%)$ and decreased after the implementation of the program to $(1.783 \%)$, i.e. a decrease of $(1.382 \%)$. This difference is statistically significant and is contrary to the expected results of implementing the program Privatization, this decrease may be due to a decrease in the volume of loans granted by the State, especially to companies and sectors that have been privatized, resulting in a decrease in the volume of loan repayments, or the exemption of some privatized companies or sectors from the debt granted to them before privatization as terms of sale, or due to a decrease in the efficiency of the collection of these loan installments. 
d. The implementation of the privatization program led to an increase in the percentage of current expenditures to the size of the general budget, which amounted to (78.387\%) before privatization and increased after privatization to $(84.418 \%)$, an increase of $(6.031 \%)$. This difference is statistically significant and contrary to the expectations of privatization programs in general, and contrary to what the previous studies reached such as Sheshinski\& Lopez-Calva (2003); Hassouna, et al (2009), but it agrees with Yar.et al (2013), which concluded that privatization did not have a positive effect on Pakistan's budget deficit.

e. The implementation of the Privatization Program did not affect the percentage of investment expenditures to the size of the general budget of the State. The percentage before privatization was $(22.50 \%)$, decreased to $(20.705 \%)$ after privatization, i.e. a decrease of $(1.801 \%)$, this decrease is not considered statistically significant, and this result is contrary to the expectations of privatization. The result is contrary to the findings of the study of the Privatization Executive Commission (2006), which indicated that the implementation of the Privatization Program led to the exemption of the Jordanian government from the burden of financial bleeding and the government support it provides to the losing companies, even if these results were actually achieved to reflect the state revenues and actual expenses as contained in the final account.

\subsection{Recommendations}

Based on the findings of the study, the researchers recommend the following:

A. Planning and preparation for the implementation of strategic programs such as privatization. In reviewing the requirements for the success of the privatization programs, the study showed that the privatization program in Jordan started before the legal framework governing the implementation process and the disposal of the returns, the program was completed before the legal framework was finalized.

B. The need to adhere to best practices and procedures universally recognized in the implementation of strategic programs and projects, the study showed that the Privatization Program did not improve the contribution of local revenues in financing the public budget. At the same time, the Privatization Committee's report pointed to the government's lack of compliance with the best practices for privatization, this can be reflected negatively on the size of the proceeds of privatization, or the volume of annual contributions from privatized companies and in all cases also negatively affect the size of public revenues of the state.

C. To take into account the factors that help the strategic programs to achieve their objectives, in the case of privatization program was supposed to be accompanied by a program to control government spending so that it can achieve its objectives, the study showed that the percentage of current expenditures to the total budget of the state witnessed a noticeable increase after the implementation of the program rather than lowering it, which indicates that the implementation of privatization program is not accompanied by programs to control and rationalize government spending.

\section{References}

Aharoni, Y. (1996). On measuring the success of privatization, privatization critical perspective on the world economy. Rutledge, London, U.K.1996

Al-Atoum, S., \& Al-Arouri, F. (2000). Statistical Methods (1st ed.). Dar Al-Manahej for Publishing and Distribution, Amman Jordan.

Al-Jundi, N. (2015). The Impact of Privatization on the Financial and Operational Performance of privatized Companies and on the State Budget in Jordan. Unpublished PhD thesis

Al-Zaareer, M. (2004) Privatization Policy. Dar Al-Thaqafa Library for Publishing and Distribution, Amman Jordan.

Awaqleh, Q. (2004). The Effect of Privatization of Public Sector Enterprises on Public Budget in Jordan. Unpublished Master Thesis, Al-Bayt University, Jordan.

Beddari, H. (2011). Fiscal and Macroeconomic impact of privatization, The Case of Zambia. University of Gothenburg, School of business, economic and law, department of economic, Autumn term,2011.

Davis, L., Ossowski, R., Richardson, H., \& Barnett, S. (2000). Fiscal and Macroeconomic Impact of Privatization. Occasional Paper 194, International Monetary Fund.

Dewnnter, K., \& Malatesta, P. (1997). Public Offering of state - Owned and privately -Owned Enterprises: An international Comparison. The journal of finance, 2(4).

Filipovic, A. (2005). Impact of privatization on economic growth. Issues in Political Economy, 14.

Gangadharan, S., \& Gurusamy, S. (2012). Reducing public debt, is it realizable objective of privatization. 
Garvalho, M., \& Antonio, S. (2001). Privatization, Public Debts and Deficit in Brazil. Institute of applied Economic Research (IPEA), IPEA working Paper No 847.

Hassouna, A., AkuRashida, A., Al-Mubaidain, B., \& Lana, S. (1999) Privatization of Privately Owned Enterprises, its Objectives and Constraints (Applied Study on Jordanian Industrial Companies), Al Isra Private University, Amman, Jordan.

Ibrahim, M., \& Saida, M. (2013). The Impact of Strategic Partner on the Financial and Operational Performance and the Investment Gravity of the Company: A Study of Jordanian Joint Stock Companies that entered into Strategic Partnerships.

Ismail, I., \& Adas, N. (2010). Government Accounting, Al Yazuri Scientific Dar, Amman, Jordan.

Kannan, T. (2001). State -Owned enterprises in the middle east and north Africa. Working paper, the economic research forum for the Arab countries, Iran and Turkey, the American university in Cairo press, Cairo, Egypt.

Katsoulaks, Y., \& Likoyanni, E. (2002). Fiscal and Macroeconomic effect of privatization.

Khader, H. (2003). Infrastructure Privatization, Development Bridge Series. Issue 18, Second Year, Arab Planning Institute, Kuwait.

Kibikyo, D. (2011). Fiscal Impact of Privatization in Uganda (1992-2007). African journal of Political science and international relations, 5(7).

Lotfi, A. (2010). Privatization Programs in the Arab World (Analytical Study), Arab Organization for Administrative Development. Research and Studies, 473.

Mansour, A. (2006). The budgetary Impact of Privatization. IMF Working Paper WP/87/68.

Ministry of Finance. (2005). General Government Finance Bulletin (1995-2005). Amman, Jordan.

Ministry of Finance. (2008). Law of Organizing the Public Budget No. 58 of 2008.

Omran, M. (2001). Detecting the performance sequences of privatizing Egyptian state-owned enterprises, Does ownership structure really matter? Working paper, the Arab academy for science and technology, College of management and technology, Alexandria, Egypt.

Oqdeh, L., \& Abu Nassar, M. (2011). The Effect of Privatization on Firms Financial and Operating Performance, evidence From Jordan. Dirasat Administrative Sciences, 38, 288-303.

Qandh, S. (2003). Privatization the latest models of economic development, Dar Majdalawi for Publishing and Distribution, Amman, Jordan.

Roger, C., \& Nilgun, G. (2009). The Impact of Restructuring and Privatization of Public Institutions in the Infrastructure and other Sectors in Jordan (1994-2008).Report of the Executive Commission for Privatization, funded by the European Union, Issue No. 1 (June 2009).

Sekaran, U. (1992). Research methods for business (2nd ed.). John Wiley\& Sons, Inc, Toronto, Canada

Shehadeh, K. (2002). Through Privatization: Thoughts on the Drawing of Arab Countries, UNDP, translated by GhassanGhosn, Development Information Unit for Arab States.

Sheshinski, E., Lopez, C., \& Luis, F. (2003). Privatization and its benefits, theory and evidence. CESIFO studies, 49(3), 429-459.

Shubaki, Y., \& Abu Shamala, A. (2012). Government Accounting. Dar Al Thaqafa for Publishing and Distribution, Amman, Jordan.

Sunderland, A. (2011). Fiscal impact of privatization in developing countries. Retrieved from http://scholarship.claremont.edu/cmc_theses/

The Executive Authority for Privatization. (2000). National Privatization Strategy, Executive Privatization Authority, Amman, Jordan.

The Executive Authority for Privatization. (2000). Privatization Law No. 25 of 2000.

The Executive Authority for Privatization. (2006). Impact of Privatization in Jordan, Executive Privatization Authority, Amman, Jordan.

Yar, A., Arif, M., \& AbdelRahim, R. (2013). Privatization and Fiscal deficit; A case of Pakistan. Research Journal of finance and accounting, 12(2). 


\section{Copyrights}

Copyright for this article is retained by the author(s), with first publication rights granted to the journal.

This is an open-access article distributed under the terms and conditions of the Creative Commons Attribution license (http://creativecommons.org/licenses/by/4.0/). 